\title{
Trend data for administration of medications in patients with acute cerebrovascular accidents and its sequelae
}

\author{
Oksana Levytska ${ }^{1}$, Bohdan HromovyK ${ }^{1}$, Nataliya Yavorska ${ }^{2 *}$ \\ ${ }^{1}$ Department of Organization and Economics of Pharmacy, Danylo Halytsky Lviv National Medical University, Lviv, Ukraine \\ ${ }^{2}$ Department of Neurology and Neurosurgery, Danylo Halytsky Lviv National Medical University, Lviv, Ukraine
}

\begin{tabular}{l}
\hline ARTICLE INFO \\
\hline Received 12 June 2017 \\
Accepted 21 July 2017
\end{tabular}

\section{Keywords:}

acute cerebrovascular accidents,

medications,

drug utilization.

\begin{abstract}
The trends in drug utilization in patients with acute cerebrovascular accidents (ACVA) and its sequelae were investigated in the Neurological Department of Lviv Regional Hospital, Ukraine, in 2007 and 2015. From the 10 anatomical groups of the Anatomical Therapeutic Chemical (ATC) classification system, in 2007, 181 medications were prescribed for treatment of ACVA and concomitant diseases, compared to 198 medications in 2015. The medications of Group C (Cardiovascular system) were of the maximal proportion in both analyzed periods (28.1\% in 2007 and $29.8 \%$ in 2015). Moreover, the largest proportion of the prescribed medications of the 3rd level groups of the ATC classification system were of group B01A - "Antithrombotic agents" (7.2\% in 2007 and 6.6\% in 2015). Furthermore, three medications (Magnesium sulfate, L-lysini aescinas and Potassium chloride) were prescribed for $50 \%$ and more patients in both analyzed periods, while the prescriptions of other medications were characterized by high variability. ATC/DDD analysis also revealed the tendency toward an increase in prescription and drug utilization of the main medication groups, and that these were used for nonspecific and specific therapy for ACVA, as well as for secondary prevention (antihypertensives, anticoagulants, antiplatelet agents and statins). Totally, the drug utilization of these medication groups was $38.5 \%$ in 2007 and $58.0 \%$, respectively, in 2015, compared to the overall number of DDDs. The results of our study suggest the existence of a positive tendency in prescriptions, and of compliance with the current principles of treatment, in patients with ACVA, in Ukraine.
\end{abstract}

\section{INTRODUCTION}

Medication use studies are very important in patients with acute cerebrovascular accidents (ACVA), including stroke. Still, despite great efforts, the problem of ACVA is not solved both in the world and in Ukraine. Approximately 16 millions of stroke cases are recorded every year worldwide, and $2 / 3$ of these are in middle- and low-income countries. Of note, the maximal prevalence of these is in Eastern Europe countries. According to the WHO data, stroke mortality tends to increase in the world: the rate was 5.7 millions cases in 2005, but in 2030, the estimated rate will be 7.8 million [1]. Therefore, in 2015, the European Stroke Organisation has begun a 5-year project ESO-EAST (European Stroke Organisation - Enhancing and Accelerating Stroke Treatment). ESO-EAST is the first comprehensive programme for improving stroke care in Europe. Initiated by the European Stroke Organisation, it has been implemented in Eastern

\footnotetext{
* Corresponding author

e-mail: yavorskanataliya@gmail.com
}

European countries through the participation of the stroke professionals, professional organisations and local authorities of all these countries [2]. The purpose of the project is to improve stroke care and reduce the global burden of stroke, including that within Ukraine. The premise of the notion is that the quality of medical care depends, among others, on the usage of safe medications with approved effectiveness. Moreover, that the continuous monitoring for their drug utilization can improve medication treatment for ACVA. In Ukraine, medical and technological documents on standardization of medical care for stroke [3,4] were approved and implemented in 2012-2014. These were developed based on the best current international guidelines, instructions and recommendations [5-7]. The documents include the information on the main medicament groups applied for nonspecific and specific therapy for ACVA, as well as that for secondary prevention (antihypertensives, anticoagulants, antiplatelet agents and statins). In this paper, 
the impact of these documents on patterns for prescription and drug utilization for ACVA is investigated.

Study objective. To evaluate the tendency in drug prescription and utilization in patients with ACVA and its sequelae, taking into account standard guidelines.

\section{MATERIALS AND METHODS}

Our study (retrospective, clinical epidemiological and pharmacoepidemiological) is based on the medical records and treatment sheets of hospitalized patients with ACVA in the Neurological Department of Lviv Regional Hospital in 2007 and 2015. In 2007, 262 medical records and 236 treatment sheets were analysed, while 300 medical records and treatment sheets were assessed in 2015. We used an epidemiological method, comparative analysis (based on content, frequency and ATC/DDD analyses [8]), as well as generalization. The statistical assessment of results was performed using program Statistica 10 Trial. Herein, a comparison of qualitative variables (sex), as well as quantitative measures (age, the number of concomitant diseases (CD) and the duration of the treatment) were performed. Mean values with standard deviations (SD) were then calculated for the obtained results, while the Shapiro-Wilk test was subsequently used to assess the normality of data distribution in populations. As we found that the data distribution was not normal, nonparametric methods were then employed for the analysis. Finally, quantitative measures were compared by Kolmogorov-Smirnov test, and qualitative variables were assessed using Pearson's chi-square test. The differences were considered significant at $\mathrm{p}<0.05$ [9].

\section{STUDY RESULTS AND DISCUSSION}

Based on the analysis of the medical reports of the participating neurological patients utilizing ICD-10 (international classification of diseases $-10^{\text {th }}$ revision), ACVA patients were distributed depending on the type of cerebral vascular disorders [10]. Of note, in our data, the total number of cerebral vascular disorders is more than $100 \%$ because 2 diagnoses (cerebral infarction and sequelae of cerebrovascular disease) were indicated in some patients' medical records in 2015 .

In accordance with our findings, half of all diagnosed cerebral vascular disorders were cerebral infarctions $(53.8 \%$ in 2007 and $50.3 \%$ in 2015) (Fig. 1). However, the patients with sequelae of cerebrovascular disease were 1.2 times more in 2015 (44.3\%), compared with 2007 (35.5\%). Moreover, hemorrhagic stroke (brain hemorrhages, subarachnoid haemorrhages, etc) was diagnosed in $10.7 \%$ of all patients in 2007 and $8.7 \%$ in 2015 .

Clinical epidemiological analysis showed that ACVA occurred more frequently in male patients (see Table 1), but the proportions of male and female patients were similar (1.5:1 and 1.6:1 in 2007 and 2015, respectively). Statistically significant differences between males and females were not detected for 2007 and $2015\left(\chi^{2}=.0057509 ; p=.93955\right)$.

A maximal number of hospitalizations was seen for male patients at working age, 50-59 years old (26.5\% in 2007 and $36.6 \%$ in 2015 p.). This number increased 1.4 times in 2015.
For females, the maximal number of hospitalizations was also seen in one age group - 70-79 years old (28.1\% in 2007 and $25.6 \%$ in 2015 p.). Still, the tendency is unfavourable for women aged 40-49 years: the number of hospitalization in 2015 was twice as many as in $2007(17.1 \%$ and $8.7 \%$, respectively).

In 2007, the patient age ranged from 18 to 88 years, the average age was $(\mathrm{m} \pm \mathrm{SD})-62.3 \pm 13.7$ years (median - 64 years, $25 \%-54.3$ years, $75 \%-73.1$ years). In 2015 , the patient age ranged from 18 to 96 years, the average age was $60.0 \pm 14.6$ years (median -59 years, $25 \%-51.3$ years, $75 \%-71$ years). Statistically significant differences were detected for patient age in these years $(\mathrm{p}<0.025)$.

In our work, ACVA was seen to be often associated with CD. The proportion of patients with CD was $74.0 \%$ in 2007 and $96.7 \%$ in 2015 . The minimal number of CD for both analyzed periods was 1 and maximal number was 14 . The mean number of CD was $2,7 \pm 2,66$ (median $-2 \mathrm{CD}, 25 \%-$ $0 \mathrm{CD}, 75 \%-5 \mathrm{CD}$ ) in 2007, and 4,4 $\pm 2,27$ in 2015 (median $-4 \mathrm{CD}, 25 \%-3 \mathrm{CD}, 75 \%-6 \mathrm{CD})$. Statistically significant differences were detected for $\mathrm{CD}$ in the patient-participants for the analyzed periods $(\mathrm{p}<0.001)$.

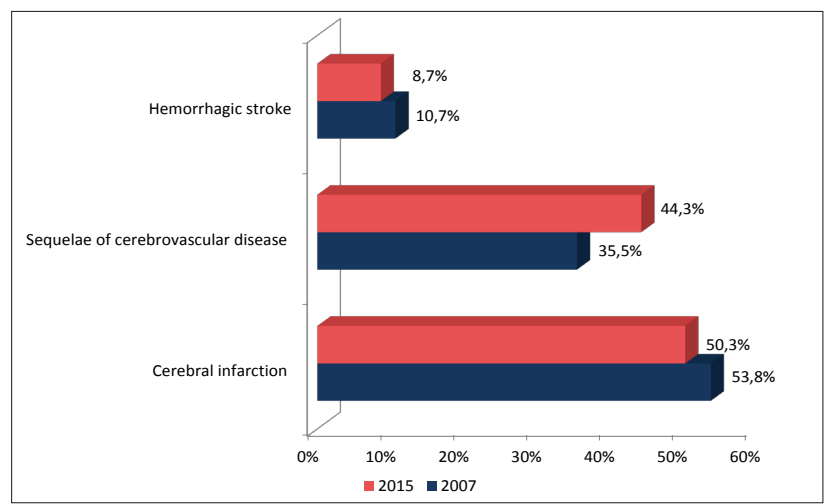

Figure 1. The proportion of patients by cerebrovascular in 2007 and 2015

Table 1. Patient distribution by age and sex, $\%$

\begin{tabular}{|l|c|c|c|c|}
\hline \multirow{2}{*}{ Age group, years } & \multicolumn{2}{|c}{2007} & \multicolumn{2}{c|}{2015} \\
\cline { 2 - 5 } & male & female & male & female \\
\cline { 2 - 5 } & $\mathrm{n}=159$ & $\mathrm{n}=103$ & $\mathrm{n}=183$ & $\mathrm{n}=117$ \\
\hline $15-19$ & 0.6 & - & 0.5 & 0.9 \\
\hline $20-29$ & 1.9 & 1.0 & 1.1 & 0.9 \\
\hline $30-39$ & 5.0 & 2.9 & 7.1 & 5.1 \\
\hline $40-49$ & 11.9 & 8.7 & 13.7 & 17.1 \\
\hline $50-59$ & 26.5 & 19.4 & 36.6 & 16.3 \\
\hline $60-69$ & 24.5 & 26.2 & 20.2 & 18.8 \\
\hline $70-79$ & 24.5 & 28.1 & 14.8 & 25.6 \\
\hline 80 and older & 5.0 & 13.6 & 6.0 & 15.3 \\
\hline
\end{tabular}

Table 2. Main CD associated with ACVA

\begin{tabular}{|l|l|l|}
\hline \multirow{2}{*}{\multicolumn{1}{|c|}{ Type of CD }} & \multicolumn{2}{c|}{ Proportion, \% } \\
\cline { 2 - 3 } & 2007 & 2015 \\
\hline Arterial hypertension (AH) & 50,3 & 82,0 \\
\hline Heart faluire & 27,5 & 57,7 \\
\hline Coronary heart disease (CHD) & 31,7 & 51,3 \\
\hline
\end{tabular}


An analysis of CD structure revealed the prevalence of cardiovascular diseases (see Table 2). In our study, the number of individuals diagnosed with arterial hypertension (AH) and coronary heart disease (CHD) increased 1.6 times, while heart failure increased 2.1 times between 2007 and 2015.

In 2007, the minimal duration of hospitalization was 1 in-patient day, and maximal was 57 in-patient days. The mean value for duration of hospitalization was $17.1 \pm 10.23$ days (median - 15 in-patient days, $25 \%$ - 10 in-patient days, $75 \%-21$ in-patient days).

In 2015, the minimal duration of hospitalization was 3 in-patient days, while maximal was 43 in-patient days, and mean $-13.1 \pm 6.99$ in-patient days (median -11 in-patient days, $25 \%-8$ in-patient days, $75 \%-17$ in-patient days) $(\mathrm{p}<0.001)$. Hence, the differences of analyzed sets were statistically significant.

Content-analysis of treatment sheets revealed that 181 medications were prescribed for the treatment of main and concomitant diseases in 2007, compared to 198 medications in 2015 - according to International Non-proprietary Name (INN) and nonproprietary name (NPN) from 10 anatomical groups of Anatomical Therapeutic Chemical (ATC) classification system. What is more, the medications of Group C (Cardiovascular system) had the maximal proportion in both analyzed periods ( $28.1 \%$ in 2007 and $29.8 \%$ in 2015 ), and this proportion increased.

Our data show that group B01A - "Antithrombotic agents", made up the largest proportion of the prescribed medications of the 3 rd level groups (therapeutic subgroups). In $2007,7.2 \%$ of all prescribed medications was from this group and, in 2015, such medications were $6.6 \%$ of the total. The second common group was subgroup N06B Psychostimulants. These are agents used for attention deficit hyperactivity disorders (ADHD), and nootropics. In 2007, $6.6 \%$ of all medications were from this group, and for 2015 , $6.1 \%$ of the total. The analysis also included medications that were used in at least $10 \%$ patients. Such medications were 21 in 2007 and 16 in 2015.

Table 3 shows that 11 medications (Magnesium sulfate, L-lysini aescinas, Potassium chloride, Furosemide, Cerebrolysin ${ }^{\circledR}$, Ipidacrine etc.) were prescribed for $10 \%$ and more patients during the analyzed periods. As revealed, the first 3 medications were used in $50 \%$ and more patients, still, in 2015 , as compared with the data for 2007, the prescription of the aforementioned medications slightly decreased, as did the prescription of the three other medications (Thiotriazoline, Ceftriaxone and Nicergoline). In contrast, the usage of Ipidacrine slightly increased in 2015. However, the prescription of Furosemide, Piracetam, Enalapril, Neostigmine bromide etc. significantly decreased by $1.5-10$ times, depending on the medication, with the prescription of Enalapril decreasing most significantly (by 10 times).

Hypertension is known as the most common and important risk factor for stroke, therefore the control of hypertension plays a key role in the prevention and treatment of ACVA. Various groups of medications (diuretics, $\beta$-blockers, calcium channel blockers, $\alpha$-blockers, angiotensin-converting enzyme (ACE) inhibitors, angiotensin II receptor blocker etc.) are also administered for this purpose.
The aforementioned enalapril is an ACE inhibitor, and is applied for treating hypertension. The modern tendency for treatment of hypertension is the usage of combined antihypertensive therapy that has an impact on various pathogenic mechanisms in order to increase antihypertensive effects [11]. This change in therapy is reflected in the decreased prescription of enalapril.

Table 3. Medications that were used in at least $10 \%$ patients

\begin{tabular}{|c|c|c|c|c|}
\hline \multirow{2}{*}{ INN/NPN or TN } & \multirow{2}{*}{ ATC - code } & \multicolumn{2}{|c|}{$\begin{array}{c}\text { Proportion } \\
\text { of patients, \% }\end{array}$} & \multirow{2}{*}{ Tendency } \\
\hline & & 2007 & 2015 & \\
\hline Magnesium sulfate & B05XA05 & 69.9 & 66.7 & slightly decreased \\
\hline L-lysini aescinas & C05CX03 & 68.6 & 65.0 & slightly decreased \\
\hline Potassium chloride & B05XA01 & 59.3 & 51.0 & slightly decreased \\
\hline Furosemidum & C03CA01 & 53.8 & 15.3 & $\downarrow$ by 3.5 times \\
\hline Cerebrolysin $®$ & N06BX22 & 44.9 & 29.3 & $\downarrow$ by 1.5 times \\
\hline Ipidacrine & N07AA07 & 32.2 & 33.3 & slightly increased \\
\hline Piracetam & N06BX03 & 31.4 & 7.7 & $\downarrow$ by 4.1 times \\
\hline Acetylsalicylic acid & B01AC06 & 30.9 & 16.0 & $\downarrow$ by 1.9 times \\
\hline Nerviplex & A11DB & 25.8 & - & not prescribed \\
\hline Dexamethason & $\mathrm{H} 02 \mathrm{AB} 02$ & 25.4 & 16.3 & $\downarrow$ by 1.6 times \\
\hline Enalapril & C09AA02 & 23.3 & 2.33 & $\downarrow$ by 10 times \\
\hline Thiotriazoline & A05BA50 & 17.8 & 14.0 & slightly decreased \\
\hline Rheosorbilact $®$ & B05XA31 & 14.8 & 7.3 & $\downarrow$ by 2.0 times \\
\hline Papaverine & A03AD01 & 14.4 & 5.3 & $\downarrow$ by 2.7 times \\
\hline Enoxaparin & B01AB05 & 14.4 & 32.2 & $\uparrow$ by 2.2 times \\
\hline Bendazol & $\mathrm{C} 04 \mathrm{~A} \times 31$ & 13.6 & 3.0 & $\downarrow$ by 4.5 times \\
\hline Ceftriaxone & J01DD04 & 12.7 & 11.0 & slightly decreased \\
\hline Neostigmine bromide & N07AA01 & 12.3 & 1.6 & $\downarrow$ by 7.7 times \\
\hline $\begin{array}{l}\text { Trimethylhydrazinium } \\
\text { propionate }\end{array}$ & C01EB20 & 11.9 & 3.6 & $\downarrow$ by 3.3 times \\
\hline Nicergoline & C04AE02 & 10.2 & 7.0 & slightly decreased \\
\hline Dextrose & В05BA03 & 10.2 & 2.0 & $\downarrow$ by 5.1 times \\
\hline Atorvastatin & C10AA05 & 8.9 & 27.3 & $\uparrow$ by 3.1 times \\
\hline Choline alfoscerate & N07AX02 & - & 22.0 & - \\
\hline Asparaginase $\mathrm{K}-\mathrm{Mg}$ & A12CC55 & 5.9 & 15.3 & $\uparrow$ by 2.6 times \\
\hline Cardiomagnyl & B01AC56 & 5.5 & 15.0 & $\uparrow$ by 2.7 times \\
\hline Vitaxon & A11DB & - & 13.7 & - \\
\hline
\end{tabular}

In 2015, as revealed, Nerviplex were not prescribed, although one quarter of all patients received this medication in 2007. However, in 2015, it can be noticed that Vitaxon were administered to almost $14 \%$ of all patients. Since both medications contain Vitamin B-complex: B1 (thiamine chloride), B6 and B12, our results reflect a change in physician preference.

As evidenced in our study, the prescription of such medications as enoxaparin, atorvastatin, asparaginase $\mathrm{K}-\mathrm{Mg}$ and Cardiomagnyl (a drug containing acetylsalicylic acid and magnesium hydroxide) increased by $2.2 ; 3.1 ; 2.6$ and 2.7 times, respectively, in 2015. This heightened usage reflects the application of a newer strategy for treatment and secondary prevention ACVA which includes administration of antihypertensives, antiplatelet agents and statins.

Further analyses of our obtained data showed that 25 medications from various groups were prescribed in 2007 
for the control of blood pressure in patients with ACVA, but such medications were 36 in 2015. Moreover, as indicated in our data, in 2007, some patients received several drugs (combined antihypertensive therapy), however, in 2015, such an approach was in the majority. The combined therapy was used in $6.4 \%$ patients in 2007 and $34.7 \%$ patients in 2015 . As we can see, the number of patients who received combined medications had increased by 5.4 times in 2015 . This could be one of the reasons for "loss of interest" in the sole administration of enalapril.

As mentioned above, a number of medical and technological documents on the standardization of medical care for stroke was approved and implemented between the years of 2012-2014, in Ukraine. Therefore, we further investigated the tendency in utilization of the commonly prescribed groups: antihypertensives, anticoagulants, antiplatelet agents and statins. For this purpose, frequency and ATC/ DDD analyses were used. Thus, the total number of used defined daily doses (DDDs) and the number of DDD for 100 in-patient days were calculated. In doing so, the following equation was used: DDDs/100 in-patient days $=($ DDDs $\times$ 100)/total number of in-patient days (n) (In 2007, $\mathrm{n}=4481$, and in $2015, \mathrm{n}=3942$ ). The results of the analysis are presented in Table 4.

Table 4. Characteristics for drug utilization of some groups

\begin{tabular}{|l|c|c|c|c|c|c|}
\hline \multirow{2}{*}{$\begin{array}{c}\text { Name of medication } \\
\text { group }\end{array}$} & $\begin{array}{c}|c| \\
\text { The proportion } \\
\text { of patients who } \\
\text { received the } \\
\text { medications, } \%\end{array}$ & \multicolumn{2}{|c|}{ Total DDDs } & \multicolumn{2}{|c|}{$\begin{array}{c}\text { DDDs/100 } \\
\text { inpatient days }\end{array}$} \\
\cline { 2 - 8 } & 2007 & 2015 & 2007 & 2015 & 2007 & 2015 \\
\hline Antihypertensives & 59.3 & 62.0 & 2121.9 & 3261.7 & 47.4 & 82.7 \\
\hline Statins & 15.6 & 38.0 & 436.2 & 2312.2 & 9.7 & 58.7 \\
\hline Anticoagulant & 24.4 & 43.0 & 655.6 & 1520.4 & 14.6 & 38.6 \\
\hline Antiplatelet agents & 46.5 & 46.3 & 1470.1 & 1301.0 & 32.8 & 33.0 \\
\hline
\end{tabular}

Table 4 shows that, when compared to the data of 2007 , the proportion of patients treated with statins increased by 2.4 times, and the proportion of patients treated with anticoagulants increased by 1.8 times, in 2015 . In addition, the proportion of patients treated with antihypertensives slightly increased (approximately by 3\%), while the proportion of patients treated with antiplatelet agents was similar. Thus, the absolute numbers of DDDs of antihypertensives, statins and anticoagulants increased by $1.5,5.3$ and 2.3 times, respectively. What is more, the absolute numbers of DDDs of antiplatelet agents decreased by 1.1 times, while the number of DDDs of antihypertensives, statins and anticoagulants for 100 in-patient days increased by 1.7, 6.1 and 2.6 times, respectively. However, the value for antiplatelet agents was almost the same (32.8 in 2007 and 33.0 in 2015). Therefore, we observed a tendency toward an increase in prescription and drug utilization of the majority of the analyzed medication groups. Totally, the drug utilization of these groups was $38.5 \%$ in 2007 , and $58.0 \%$ in 2015 , compared to overall number of DDDs.

\section{CONCLUSIONS}

The clinical epidemiological and pharmacoepidemiological analysis of medical records for patients from neurological departments for 2007 and 2015 has revealed the prevalence of brain infarction among the recorded cerebrovascular diseases during the investigated periods, and this disorder occurred more often in male patients. The analysis also showed a tendency toward an increase in prescription and drug utilization of the main medication groups (antihypertensives, anticoagulants, antiplatelet agents and statins) which are used for nonspecific and specific therapy for ACVA, as well as for secondary prevention. Herein, it can be seen that antihypertensives, anticoagulants, antiplatelet agents and statins are the go-to drugs, because these groups of drugs help to significantly reduce the risk of strokes. The results of our study suggest positive commitment in prescription practices and compliance with the current principles of treatment in patients with ACVA - as outlined in the new medical and technological documents on the standardization of medical care for stroke. However, some medications, which are often prescribed for stroke in Ukraine, are not included in European and American guidelines, and are not improved by FDA for this indication. Therefore, the further ongoing monitoring of pharmacotherapy is needed for tracing and improving drug utilization in patients with cerebrovascular diseases. In addition, physician knowledge must be enhanced with regard to the current guidelines for treatment of cerebrovascular diseases because some still administer groups of drugs that are without approved effectiveness in strokes.

\section{CONFLICT OF INTERESTS}

The authors do not declare a conflict of interests.

\section{REFERENCES}

1. Strong K, Mathers C, Bonita R.: Preventing stroke: saving lives around the world. Lancet Neurol., 6(2), 182, 2007.

2. ESO-EAST "Enhancing and Accelerating Stroke Treatment" [electronic source]. Available at: http://eso-stroke.org/eso-east/

3. Current principles of diagnosis and treatment of patients with acute ischemic stroke and TIA. Evidence based adapted clinical guideline: Order of MoH of Ukraine 03.08.2012 No. 602 "On approval and implementation of medical and technical documents on standardization of medical care in ischemic stroke (укр. Сучасні принципи діагностики та лікування хворих із гострим ішемічним інсультом та ТІА. Адаптована клінічна настанова, заснована на доказах: Наказ МОЗ Украйни № 602 від 03.08.2012 р. «Про затвердження та впровадження медикотехнологічних документів зі стандартизації медичної допомоги при ішемічному інсульті». [electronic source]. 2012. Available at: http://www.moz.gov.ua/ua/portal/dn_20120803_602.html)

4. On approval and implementation of medical and technical documents on standardization of medical care in hemorrhagic stroke. Order of MoH of Ukraine No. 275 dated 17 april 2014 (укр. Про затвердження та впровадження медико-технологічних документів зі стандартизачії медичної допомоги при геморагічному інсульті. Наказ МОЗ України № 275 від 17 квітня 2014) [electronic source]. 2014. Available at: http://www.moz.gov.ua/ ua/portal/dn_20140417_0275.html 
5. European Stroke Organisation. Guidelines for Management of Ischaemic Stroke. 2008. [electronic source]. Available at: http://www. eso-stroke.org/recommendations.php

6. Guidelines for the Early Management of Adults With Ischemic Stroke: a Guideline From the American Heart Association/ American Stroke Association Stroke Council, Clinical Cardiology Council, Cardiovascular Radiology and Intervention Council, and the Atherosclerotic Peripheral Vascular Disease and Quality of Care Outcomes in Research Interdisciplinary Working Groups. 2007. [electronic source]. Available at: http://stroke.ahajournals.org/ content/38/5/1655.short

7. Guidelines for the Prevention of Stroke in Patients With Stroke or Transient Ischemic Attack: a Guideline for Healthcare Professionals From the American Heart Association/American Stroke Association. 2011. [electronic source]. Available at: http://stroke.ahajournals.org/ content/42/1/227.full.pdf
8. ATC/DDD methodology [electronic source]. Available at: https://www. whocc.no/atc_ddd_methodology/purpose_of_the_atc_ddd_system/

9. Campbell, M.J., Machin, D., Walters, S.J. 2007. Medical Statistics: A Text Book for the Health Sciences, $4^{\text {th }}$ edn. Chichester: WileyBlackwell Press; p. 344.

10. International Statistical Classification of Diseases and Related Health Problems, $10^{\text {th }}$ Revision [electronic source]. Available at: http://www. who.int/classifications/icd/ICD10Volume2_en_2010.pdf

11. ESH/ESC Guidelines for the management of arterial hypertension. The Task Force for the management of arterial hypertension of the European Society of Hypertension (ESH) and of the European Society of Cardiology (ESC). [electronic source]. Available at: https:// academic.oup.com/eurheartj/article/34/28/2159/451304 